\title{
The Gainers Strike: Capitalist Offensive, Militancy, and the Politics of Industrial Relations in Canada
}

\section{ALAIN NOËL AND KEITH GARDNER}

The unions are very self-serving. In Taiwan workers get $\$ 300$ a month for the same job. And Taiwan isn't that far away by air. They need to find out what the new realities of business are.

Peter Pocklington, Alberta Report, 16 June 1986.

You know, it was a very little strike at a very little plant in a very unimportant city. But it took on that kind of significance -they realized they had to win just as badly as we realized we had to win.

Dave Werlin Saturday Night, August 1987.

7 he history of Alberta's meatpacking workers is closely connected with the broader historical struggles of the working class in North America. Like their counterparts from the packinghouses in Toronto and Montreal, the workers of Calgary and Edmonton organized and fought for union recognition between 1911 and 1920 , thus joining a labour revolt that was spreading throughout Europe and North America in the wake of World War I and the October Revolution. ${ }^{1}$ They faced stiff resistance. Pat Burns, the Calgary millionaire who owned Burns Packing Plant and employed children for 27 cents per hour, refused to negotiate and said the company "would 
rehire the strikers as vacancies opened up but would reserve the right to choose who it would take back." The government was unwilling to challenge him and, lacking support from their international union, the Amalgamated Meat Cutters Union, the Burns workers were defeated along with those at Swifts in Edmonton. ${ }^{2}$ They remained non-unionized for almost twenty years. The Amalgamated was unable to organize the large packing houses and the Alberta Federation of Labour also failed to reach the workers of what was by 1935 the largest manufacturing industry in the province. $^{3}$

The second attempt to organize, also unsuccessful, came in 1937, when Canadian workers imitated the methods developed by the CIO in the United States. Workers' demands were finally met in the 1940s, when the United Packinghouse Workers of America, a CIO/CCL affiliate, organized a national strike and won a standardized master agreement with the 'Big Three', Swifts, Canada Packers and Burns. A national bargaining pattern was established and, until recently, it kept wages, benefits, and working conditions uniform across the country. 5

In the 1980 s, such stable bargaining patterns started to unravel. In the United States, in industry after industry multi-employer "pattern bargaining" broke down leaving the market and local union strength as the only determinants of wages and working conditions. "The worst settlements in an industry, or company, increasingly become the standard of wage determination" and, since 1983, non-union workers have obtained larger percentage wage increases than union members. Collective bargaining has often been reduced to an exercise in concession management and union membership has plummeted below 20 percent. $^{6}$

Canadian trade unions have so far been able to avert most of these trends. Concessions have been accepted but they have not reached the American level, and union membership is still strong, even in the private sector. The contrast with the American evolution was clearly established when the automobile workers formed a new Canadian union to refuse the concessions accepted by their international union. $^{7}$ 
The times remain trying however. Between 1977 and 1987 real wages dropped by 4 percent, in spite of a 30.8 percent growth in the Gross Domestic Product. ${ }^{8}$ The combination of high unemployment, conservative governments, and employers fascinated by the power of their counterparts to the South has made an American-type offensive plausible. In many cases, the struggle already concerns basic union positions, as workers fight to secure previous gains or "to hold onto the union at all."

Some observers think such pressures could weaken Canadian unions as much as their American counterparts. ${ }^{10}$ Opponents of the Free Trade Agreement, in particular, have predicted an erosion of Canadian labour laws with a gradual transition toward the American pattern. ${ }^{11}$ The divergence between the two countries, which widened as trade relations intensified, and the evidence provided by recent conflicts suggest these negative assessments may be premature. Simple celebrations of the Canadian differences would, however, be equally misguided. ${ }^{12}$ Canadian unions face a real challenge.

No economic or institutional necessity dictates the outcome. A new balance of class forces can only be the product of a series of conflicts. Specific analyses are therefore necessary to assess the transformations that are taking place and to evaluate the strengths, weaknesses, and potential of the Canadian labour movement.

In that perspective, the 1986 Gainers strike in Edmonton is instructive. A long and violent confrontation over the very existence of the union, the strike "rallied Alberta working people as no cause had since the Depression." It rejuvenated the provincial labour movement, increased public support for trade unions and brought the provincial labour laws to the forefront of the political agenda.

For a number of reasons, the Gainers case appears particularly relevant. First, the strike took place in meatpacking, a mass-production industry that is undergoing profound transformations. In the United States, meatpacking has increasingly become a non-union, low-wage industry. In Canada, with the same international union, similar pressures are at play. Conflicts in the industry can therefore indicate 
how entrenched are the differences between the two countries.

Second, the strike happened in Alberta, one of the provinces, with British Columbia and Saskatchewan, where the Americanization of industrial relations seems most likely. ${ }^{14}$ Because industrial relations frameworks are constructed on precedents, the vitality of a labour movement is best observed where it is most threatened. The depressed Alberta labour market and the orientation of a provincial government, whose labour laws had already been condemned by the International Labour Organization, placed the union and the labour movement in such a vulnerable position. ${ }^{15}$

Finally, the Gainers strike is instructive because, from the outset, it was a political confrontation. Comparative studies suggest that the strength and the nature of labour movements have more to do with politics than with generic economic trends. The difference between Canada and the United States, in particular, is best explained by political and ideological factors. ${ }^{16}$ The Gainers strike critically tested that difference.

From a strict collective bargaining point of view, the strikers did not obtain very much. After more than six months of an intense and at times violent conflict, the agreement which was finally reached extended earlier concessions for a surprisingly long four-year period, and left wages well below the national standards in the meatpacking industry. Moreover, the labour movement and the New Democrats were not able to translate increased public awareness and the potential support for change into legislative victories.

In spite of these strictly defensive results the strike was perceived as successful by the workers of Alberta. Beyond its immediate outcome, it is evoking a new militancy, a rank and file determination to refuse concessions, and to demand more. If political and ideological factors are the foundations on which the comparative strength of the Canadian labour movement rests, the capacity of the Alberta workers to react to a frontal attack with militancy and with a renewed discourse indicates something important is happening. 
To better understand the political meaning of the strike, its story must be told. It is a long and complex story, and many aspects must be left aside, to focus on the major political and economic factors and evaluate the strike's legacy. The article offers a roughly chronological account of the strike with the aim of establishing the political and ideological nature of the corporate offensive that triggered it, the strength and importance of the militancy that developed, and the significance of this militancy in a context where a strong conservative government predominates.

1. From High to Low Wages: The American Model in the Meatpacking Industry In 1981, meat processing, with 5,500 employees, was the largest industrial employer in Alberta, second only to petroleum refining in terms of sales ( $\$ 1.8$ billion). Nationally, the industry ranked ninth in terms of employment and fourth in annual sales. It was a profitable Canadian-owned industry which exported more than it imported, primarily to the United States and Japan. Concentrated and stable, the industry grew steadily, practically doubling its output between 1960 and $1983 .{ }^{17}$ Growth came easily since it was generated by a rapidly expanding domestic demand, and the benefits were shared in an oligopolistic fashion by the major meatpackers. ${ }^{18}$ Given these conditions the industry became complacent. There was some modernization in the beef sector, but practically none in the pork industry. Old facilities - almost all of Alberta's were constructed before 1940 - were simply maintained. ${ }^{19}$

When domestic demand started declining in the early 1980 s, due to slower population growth, reduced disposable incomes and changing tastes, the industry was "plagued by overcapacity and inefficient, antiquated facilities." 20 In Western Canada, this decline in demand was compounded by the additional loss of the traditional Eastern market, primarily due to the Quebec government's aggressive drive to reach provincial self-sufficiency. The industry had to rationalize.

In meatpacking, rationalization cannot simply be effected through automation. A recent report on the hog industry notes that "value-added by Canadian plants still has a high 
labour component despite recent labour-saving technological changes." 21 Attempts to push automation have failed because differences between animals prevent the full standardization of operations. "Extensive manual labour" is still required: "about 50 percent or more of packing plant employees work with knives or with hand held power tools." Rationalization has mostly meant reducing wages and speeding up the pace of production, at the cost of a rising injury rate. ${ }^{22}$

In the United States, industry rationalization was rapid and the effects for workers particularly harsh. The recession caused by the Federal Reserve Board's monetarist policies prompted companies to demand major wage concessions and benefit rollbacks. ${ }^{23}$ Through reorganizations, takeovers, divestitures, chapter 11 bankruptcies, and other tactics, the industry was transformed. Mike Davis concludes:

...the meat packers have actually reversed fifty years of militant unionism and "model" bargaining to convert a high wage industry into a low wage, non-union sector (wage slashes in pork packing have averaged fifty percent or more) $\ldots{ }^{24}$

Not surprisingly, Canadian employers soon called for the same, and they were encouraged by learned reports from industry and academic economists claiming that competitiveness required an elimination of the new "wage differential" with the United States. ${ }^{25}$

In fact the Canadian industry has remained competitive even with higher wages: exports of meat products "almost doubled in value between 1980 and 1985."26 Previously a large net importer of American pork, Canada "has become an increasingly larger net exporter of pork to the U.S. market." ${ }^{27}$ Industry experts usually explain this success by referring to the decline in the relative value of the Canadian dollar. ${ }^{28}$ They may regret the higher Canadian wages, but admit they do not constitute an immediate problem. Only "the medium-term and/or long-term competitiveness of some Canadian plants could be threatened by units located in the U.S." (emphasis added). ${ }^{29}$

Ironically, the real immediate threat comes from the American reaction to the Canadian industry's success. 
Claiming the Canadians are unfairly subsidized, American producers have sought and obtained protectionist measures. Countervailing duties have been applied to live hogs since 1985 and in June 1987 the Senate voted to extend these duties to all pork products, to curtail the still growing Canadian shipments. ${ }^{30}$

The pressure for lower wages came from within the national industry. In the 1980 s, the drop in domestic demand for red meat forced the major companies to restructure, while new methods encouraged the rise of smaller, single purpose plants, which often located in rural areas where they could pay lower wages. In an industry where barriers to entry are limited and where product differentiation matters little, new competitors were bound to affect industrial relations. ${ }^{31}$ Alberta was among the first battlegrounds.

\section{Meatpacking in Alberta: From Boom to Bust In 1982,} after amicable negotiations, a nationwide settlement covering Canada Packers, Gainers, Intercontinental Packers, and Burns Meats was reached. It provided for wage increases of 12 percent and 11 percent over two years as well as improvements in pensions, statutory holidays, vacations, and health and welfare benefits. Two years later, this pattern, typical of the postwar era, was challenged by events in Alberta, the first province where meatpacking unions were defeated. $^{32}$

By 1984, much had changed in Alberta. Hardly affected by the world economic crisis in the seventies, the province was hit when the "monetarist shock" of 1981 generated a worldwide recession. The drop in world demand for oil and gas ended a twenty year period of rapid expansion in Alberta. ${ }^{33}$ To make matters worse, the provincial government followed Ottawa and adopted cyclical, restrictive budgetary policies. ${ }^{34}$ Unemployment increased, from a rate of 3.8 percent in 1981 to 11.2 percent in $1984 .{ }^{35}$ By the summer of 1984, conditions were ripe for the offensive against unions which began in the meatpacking industry.

The Conservative government, which had already adopted many measures against public sector unions and allowed contractors to undermine construction unions 
through legal actions, gave its tacit support when it stated that in agriculture processing, "input costs, such as wages, rigidity of work rules, and primary product costs, tend to place Alberta manufacturers at some disadvantage. The high cost of wages in Alberta relative to most other jurisdictions reduces our competitive opportunity." This position, which conveniently ignored the existence of a national wage pattern, was maintained and extended when, in February 1986, Labour Minister Les Young suggested that lower wage increases were the solution to the high rate of unemployment in the province. ${ }^{36}$

When the nation-wide meatpacking strike began in June 1984, Lakeside Industries, a small independent meat packer, used the occasion to break the union local and to outmaneuver its competitors. As soon as the strike began the company hired replacement workers at wages 30 percent below the union rate, a cut that ranged between $\$ 3.00$ and $\$ 3.80$ an hour. With this cost advantage, Lakeside benefited from the abundant supply of cattle and the large demand for meat created by the national strike that affected its main competitors. Late in July the company was able to double its production by adding a second shift and by the end of the year it had become the fifth packer and the largest single cattle plant in Canada. ${ }^{37} \mathrm{~A}$ handful of workers, twenty-two in December 1986, continued the strike until the action was abandoned by the UFCW, in November $1987 .^{38}$

The same summer, in July, the workers at Gainers' Edmonton plant faced a similar situation. With their contract expiring, and negotiations and strikes continuing in the rest of the industry, workers were preparing to strike. But the quiet settlement of 1982 would not be repeated. During the preceding winter, Peter Pocklington, the owner of Gainers and self-appointed champion of private enterprise, hired at great expense a new president for his Edmonton plant, A. Leo Bolanes, an American executive with a reputation for turning meatpacking plants into highly profitable operations. The signal was clear: Gainers was planning to move away from the Canadian pattern, and introduce in Alberta the methods developed in the American meatpacking industry. ${ }^{39}$ Immediately before the strike deadline, Gainers 
bought full-page newspaper advertisements to recruit replacement workers, offering a wage of $\$ 6.99$ per hour, well below the union rate of $\$ 11.99$. At the time, approximately 1,200 meat workers were unemployed in the province because of the restructuring of the industry, which had led in 1983 and 1984 to the closure of Grande Prairie Packers, Canada Packers in Edmonton and Burns Foods in Calgary. Gainers could easily recruit an experienced workforce from this large pool of unemployed workers. On July 6, as the strike was being planned, more than 1,000 job-seekers lined up on 66th Street, outside the Gainers plant, ready to replace the strikers. ${ }^{40}$ Dave Werlin, president of the Alberta Federation of Labour, explains:

The workers were not prepared for it. They had to decide in a very hurried fashion whether to take this on without preparation or to bite the bullet, so to speak, and to accept major concessions, and they did the latter. They went back in. There was an agreement arrived at in just a matter of hours...

The strike was called off, talks resumed and an agreement was reached. The reactions of the rank and file were mixed, but the union-backed offer was accepted (454 for, and 331 against). ${ }^{42}$ The new contract froze wages for two years and created a two-tier wage structure whereby new employees would get forty percent below the current rate $(\$ 7.00$ per hour rather than $\$ 11.99$ ). Benefits related to the vision care plan, statutory holidays and overtime rates were also lost. ${ }^{43}$

The contract was a major victory for Gainers since it decidedly broke the nationwide bargaining pattern, to the dismay of the UFCW national officers who were then negotiating with trend-setting Canada Packers. They felt the contract was "terrible, absolutely disastrous," and it indeed helped Burns and Canada Packers obtain concessions. ${ }^{44} \mathrm{At}$ the time, John Ventura, then the assistant chief steward of the union and its president by 1986 , concluded that the workers had no choice given the economic situation and the threat posed by the strikebreakers. ${ }^{45}$ In retrospect his evaluation, which was adopted against the advice of the UFCW officials, may be questioned. ${ }^{46}$ To be fair, however, any assessment of the local's decision should take into con- 
sideration the previous period of prosperity and conservatism, which did not prepare the union for what happened.

The next two years were good for Gainers. With wage rates well below those paid by its competitors and the lowest hog prices in Canada, the company doubled its capacity and increased productivity on the hog-killing floor by 108 percent, at the cost of an increase in industrial accidents. By 1986, Gainers reached an output of 7.5 million pounds a week, up from 2.5 million pounds in $1984 .^{47}$ Pocklington could invest heavily to build what Alberta Report has called his "pork empire." Between 1984 and 1986, he bought three pork plants in St. Louis and one in Oakland and planned to acquire more American plants in 1986 and $1987 .^{48}$ In 1986, construction began on a new Gainers bacon processing plant in North Battleford, Saskatchewan after the city and the provincial government agreed to provide generous incentives. ${ }^{49}$ Pocklington was well on his way to realizing his goal of "a highly profitable company with $\$ 3$ billion in sales." 50

For the workers at the Edmonton plant it was, of course, a different story. The contract settlement of 1984 remained a source of bitterness in the succeeding two years. According to Dave Werlin the workers "lived the kind of life you live in a plant after a union had been rolled back and they were very, very hurt and very angry about that." ${ }^{51}$ The stage was set for a second confrontation, this time over the very existence of the union.

3. "The Battle of 66th Street" Before the strike, set for June 1, 1986, there were no negotiations between the union and Gainers. The company simply did not make an offer. On May 13, 1986, less than a week after the re-election of the Conservatives, the Edmonton Sun published the first advertisements for replacement workers. The union had not even taken a strike vote; the threat was serious since the unemployment rate was around 10 percent, with forecasts predicting 12 percent for the end of the year. ${ }^{52}$

Peter Pocklington's intentions were barely veiled by his "tough market" rhetoric. His argument that Gainers could not pay industry wages because of the additional transpor- 
tation costs absorbed by a western plant and because of the company's dependence on the American market carried little weight since most of Gainers' competitors were also in the West. ${ }^{53}$ Neither the American nor the Canadian situations made Gainers' attack on its union an economic necessity. If anything, competition encouraged prudence. In a competitive environment, the firm that leads an offensive against established industrial relations patterns bears the cost of a struggle that may affect its productivity, current profits, market shares, and public image. Fletcher's Fine Food, Gainers' competitor in Alberta, decided not to take the risk. With equivalent transportation costs and a heavier reliance on the American market, it accepted a settlement based on Canada Packers' contract, one week after strikes started at both Albertan companies. 54

Peter Pocklington's motivations were different. He was on a crusade to destroy the union local and gambled that he could set a Canadian precedent for a large urban firm in a unionized industry. Many businessmen disagreed with his ideas and methods, and some business associations talked disapprovingly of union-busting. ${ }^{55}$ But, as Pocklington explained to a reporter:

This is a very strong point of principle. We have had too damn much socialism, a socialist media, too many people wanting something for nothing. I am not going to have another collective agreement with anyone. This is the market. It will be non-union. I will tough it out, we will be producing our quality foods, we will be back to full shot. You do some things because of the principle of the thing. ${ }^{56}$

Pocklington was, in a sense, pursuing the same rightwing agenda he proposed when he ran for the leadership of the federal Conservative party in 1983. A member of the board of the right-wing Fraser Institute, Pocklington sees unions as "social monopolies" and believes, with Ayn Rand, that "an individual can most benefit others by blindly pursuing his own interests." 57 These beliefs are combined with a fondness for media attention: Pocklington has been involved in politics, has written a column for the Edmonton Sun, and owns the Edmonton hockey and Triple A baseball 
teams. More than a single pawn in a broad class attack, the owner of Gainers was the type of capitalist who could set new trends, an individual willing to pay the cost of being first, oblivious to the reaction of his unsettled competitors. The competitive logic guaranteed his corporate critics would eagerly follow his lead in the event of a victory. ${ }^{58}$

The workers were no less determined than Pocklington. After two years of concessions and a significant speed-up in production, now faced with an employer who was unwilling to acknowledge their concessions and even asked for more, the workers were ready for a tough fight. Said Dave Werlin:

The workers were met with scabs again, ready to take their jobs. But they were ready for it this time-they were psychologically ready, they were angry, and they stood their ground...once the strike commenced there was an almost spontaneous militancy..

On June 1 , in an almost festive atmosphere the workers organized their picket lines in front of the plant gates, some of them chanting "Yankee Go Home" in reference to Leo Bolanes, the American president of Gainers. They intended to settle for nothing short of parity (a parity they had maintained for more than forty years until 1984) with workers at Canada Packers, who had recently obtained an agreement. $^{60}$

The fights began immediately. For a few days, the workers were able to keep strikebreakers from entering the plant, but violent clashes resulted from Pocklington's systematic attempts to get buses through the picket lines. With the help of the Court of Queen's Bench and of the Edmonton city police he eventually succeeded. On June 2 , a first injunction was issued which restricted the number of pickets to 42, distributed in small groups more than ten feet from the plant gates. At the request of Gainers a tougher injunction was served on June 10 following further clashes between strikers and strikebreakers. This time, pickets were banned from a larger area, which included the lots where the union kept its trailer headquarters. The injunction specified that in this area "no pedestrians being more than three 
in number may halt at any time." In addition, the "use of a public address system from and in the prohibited zone" was forbidden and everyone except the members of the local was banned from picketing; the members had to sign a union register open for police inspection. ${ }^{61}$ The courts were willing to go to great lengths to protect the freedom of one entrepreneur to operate his plant, even forbidding the distribution of leaflets in front of grocery stores selling Gainers products. ${ }^{62}$ According to James C. Robb, law professor at the University of Alberta, "from a legal perspective," the injunctions were of "breath-taking magnitude." ${ }^{63}$ Judge J.C. Cavanagh, who delivered the June 10 judgement, proclaimed his neutrality: "What I'm trying to do is to restore peace and reduce the risk to our police, who are caught in the middle." The judge expressed no concern for the rights of workers to protect their jobs and to preserve the effectiveness of their main bargaining tool, the strike. For him the problem was rooted in the use union leaders made of the strike to attack Alberta's labour laws; he thought they were choosing the wrong "forum for that."

In spite of the support mayor Laurence Decore granted the strikers by visiting their picket lines, the Edmonton city police applied the court decisions diligently. In two weeks the department exhausted its entire overtime budget for the year. Hundreds of policemen, the riot squad, and at times the SWAT team arrested over four hundred "battered and bruised" workers, to enable the strikebreakers to enter the plant. Gainers was able to resume most of its operations. ${ }^{65}$

Meanwhile, the negotiations for a new contract were going nowhere. Pocklington's declarations and actions had already made it clear that he did not intend to negotiate with the union. Gainers made no written offer to the strikers between June 13 and December 1. On that date an offer was submitted to comply with a Labour Relations Board ruling that stated that Gainers had not bargained in good faith. The offer was a mere formality. As Dave Mercer, lawyer for the local explained, it was "calculated to bring about a rejection from the membership" since it allowed for the strikebreakers to keep their jobs, with a guarantee that union members would be first in line for any new open- 
ings. Phil Ponting, chief negotiator for Gainers, was explicit, stating that, "basically, all of these union people are out of a job."

The work of an Industrial Disputes Inquiry Commissioner in June and July produced negligible results. The recommendations of the Commissioner, former Labour Relations Board chairman Alex Dubensky, did not guarantee the strikebreakers would be dismissed and rejected the notion of parity with the other meatpacking companies. Dubensky chose to ignore the long established practice of a national wage standard and argued instead that wage demands should be compared with contract settlements in Alberta's other industries. The union members overwhelmingly rejected the report, as did the company, which viewed the proposed substandard wage increases as still too generous. ${ }^{67}$

The only avenues left open to the union were the courts, an appeal to public opinion, and the political arena. Not much could be expected from the courts. The impact of public opinion was more significant. A majority supported the strikers and, with documented evidence of poor quality control and a health alert issued by the federal government to recall tainted Gainers meat, the boycott launched by the union during the summer proved very effective. The Dominion, Safeway, Loblaws and Miracle Mart chains stopped selling Gainers products, and the employees of the Food For Less stores in Edmonton "had to change the price sign over the Gainers bacon displays two or three times a day because shoppers were plastering the signs with 'Boycott Gainers' stickers." 68 After the settlement "even company officials conceded that a national boycott of Gainers products had met with great success..."69

A successful national boycott could have only limited effect, however, because Gainers was reorienting itself towards the American market. Public support, although helpful, only brings results if it is translated into political strength. In their attempt to politicize the strike, the union and the Alberta labour movement focused on the issue of provincial labour laws. 
4. Alabama Labour Laws As soon as the strike began, the provincial labour laws became the subject of criticism. The Edmonton Journal condemned the strike violence and attributed it to "poor labour laws that encourage chaos rather than order." 70 The Liberal party took a similar position: it deplored the violence without explicitly blaming the company and criticized the labour laws, but only in general terms. ${ }^{71}$

Initially, the position of the New Democrats was also ambiguous. The provincial party has long downplayed labour issues in the hope of attracting the votes of the middle class - particularly farmers and small businessmen, somehow perceived to be more numerous than workers. ${ }^{72}$ As the official opposition the party nevertheless represented the most obvious opponent to the government and the dynamic of the conflict led it to take a strong stance. Bryan Strong, union leader, new MLA for St. Albert, and New Democrat Labour critic, endorsed the viewpoint of the labour movement when he explained the broader political meaning of the strike:

During the last three years, this government encouraged, by legislation, and proposed legislation such as the ill-conceived Bill 110 in the construction industry, the employer's right to unilaterally disregard collective agreements and the collective bargaining process. The advent of the 24-hour lockout for the unilateral changing of terms and conditions of employment, coupled with the ease of obtaining injunctions, makes the use of strikebreakers inevitable. ${ }^{73}$

The labour movement mobilized almost immediately and presented the strike as a "watershed" for Canadian labour - a test of union strength in hard times - and as evidence that changes were necessary in the province's labour laws, drawing parallels between the laws of Alberta and those of Alabama, Poland, Chile, Guatemala and South Africa. ${ }^{74}$ Dave Werlin, AFL president, Vair Glendenning, head of the Alberta Building Trades Council, and "representatives of virtually every union in Alberta" were among the people arrested on the Gainers picket lines. The labour movement also expressed its support through a rally on June 7 and a demonstration held at the opening of the provincial legis- 
lature five days later. That demonstration brought between six and eight thousand people to the Legislature and was attended by Shirley Carr, president of the Canadian Labour Congress, as well as representatives from the New Democrats, the trade unions and other groups from around the province. The two themes of this demonstration, the largest in Alberta since the hunger marches of the 1930s, were summed up on thousands of lawn signs that appeared around Edmonton in the following days: "Boycott Gainers-Change Labour Laws." 75

Faced with these pressures, the Conservative government had to react. While usually unwilling to intervene in industrial disputes unless compelled to do so by the necessity of maintaining 'business confidence', conservative governments do worry about major social disorders. Electoral considerations, in particular, may push them to intervene in class conflicts and to change the legislative framework. Although not all that it is claimed to be, capitalist democracy does matter. ${ }^{76}$

At first, the government denied that the shortcomings of Alberta's labour laws had anything to do with the Gainers strike. From the Conservatives' point of view, the problems raised by the strike were not symptomatic of a deeper malaise. They were, said Labour Minister Ian Reid, merely the "rare occurrence that happens when the system does not work smoothly," a consequence of "the two parties' inability to get together over the bargaining table."77 There was no need for change. Always subtle, Premier Don Getty concluded that, violence on the picket lines notwithstanding, "the laws can't be made in the streets of Alberta."

The pressure for change continued and, at the last minute, a sentence committing the government to a labour law review process was added to the final paragraph of the Throne Speech. ${ }^{79}$ The Conservatives could find no reason to justify fixing something they were convinced was not broken and they had difficulties explaining their decision to review the law. Fred Stewart, Conservative MLA for Calgary North Hill, explained the decision as well as he could:

The myth that is being perpetrated by certain members that our legislation is unlike any other province's in its discrimination 
against workers is just that; a myth. However, our legislation must always be responsive to changing circumstances, and it must constantly be reviewed... ${ }^{8}$

With regard to the differences between provinces the MLA was right. For even Manitoba with its NDP government had not forbidden the use of strikebreakers; Quebec was the exception in this. Likewise, the "back-to-work" and the permanent anti-bargaining laws imposed on public sector unions came early and were particularly severe in Alberta, but the province merely pioneered what has become a national trend. ${ }^{81}$ Overall, as the AFL leaders recognized, Alberta's labour laws were closer to the national norms than most critics allowed. ${ }^{82}$

The conflict had less to do with the province's anachronistic 'Alabama-style' labour laws than with the gradual erosion of a legal framework which was common throughout Canada. This erosion, which began in the 1980 s, was experienced in every province. ${ }^{83}$ In Alberta, as elsewhere, the process first affected the public sector workers. It rapidly spread to encompass all unionized workers in the private sector. The process has not yet achieved the same depth and breadth in other provinces, although the governments of British Columbia and Saskatchewan are now striving to follow and even outdo the Albertan model.

Specifically, the transformation of the Albertan industrial relations framework has involved the introduction of new methods which an employer can use to undermine and eventually destroy unions. The key method was first introduced in a Bill that allowed construction companies to circumvent unions by creating "spin-off" companies. Bill 110 was passed in November 1983 after intense lobbying from contractors, but was eventually shelved following strong protests by the labour movement. The legislation became unnecessary after rulings by the Labour Relations Board and the courts accomplished the Bill's purpose. Albertan companies can now use "spin-offs" as well as the "25-hour lockout," under which recognition is withdrawn and new contractual terms are unilaterally established when a collective agreement expires. 
The construction unions, which were able to defeat Bill 110 , failed to counter these anti-union legal procedures. In just a few years, a heavily unionized construction industry was transformed into a predominantly non-union sector. ${ }^{84}$ The manufacturing sector followed close behind. Lakeside Industries led the way, and was soon imitated by Zeidler Forest Industries in Slave Lake, which in July 1989 was still operating with strikebreakers who were paid reduced wages. At the Suncor oil sands plant in Fort McMurray, a five-and-a-half month lockout (now settled) was also characterized by the use of strikebreakers and by the arrest of hundreds of workers. ${ }^{85}$ Elsewhere, the pressure put on unions was less direct but sufficient to bring major concessions. ${ }^{86}$ This evolution resembles the American pattern, characterized less by legislative activism than by the steady undermining of established procedures and institutions. ${ }^{87}$

The early conflicts all involved small or remote industrial plants. Gainers was the first major urban plant to attempt permanently replacing its workers by a cheaper nonunionized workforce. But this time more than 1,000 workers who had already experienced concessions were involved. Moreover, the Alberta labour movement had changed.

All working class organizations seek stable rules, to limit the arbitrariness of employers, who easily predominate in an unregulated capitalist environment. With time, these rules, no matter how necessary or useful, tend to diminish militancy and to make the organizations vulnerable. ${ }^{88}$ In Alberta, the least unionized province, these general tendencies were compounded by the boom in the oil economy, which made class conflicts less obvious. After 1970, the average wages in the manufacturing sector were the highest in Canada, unemployment was low, and oil revenues enabled the Conservative government to offer social programs with the lowest tax rate in Canada. ${ }^{89}$ There was little impetus for militant unionism and, when the recession began, the unions felt impotent. ${ }^{90}$

By the mid-1980s, the Alberta labour movement was ready for a renewal. The Alberta Federation of Labour initiated the change when it elected, by a narrow margin, Dave Werlin, an openly Communist president, committed 
to building a militant labour movement. In 1985 , construction workers dissatisfied with their unions created the "Dandelions," a militant group of unemployed ready to "walk every picket line in Northern Alberta" and willing to organize political actions. ${ }^{91}$ The 1986 Gainers strike fueled this renewal and gave it political relevance.

Early in the strike, opposition politicians and union leaders drew attention to its political dimension. They blamed the government for allowing the use of strikebreakers and for keeping the strikers uncertain about their future status. The key problem, a common one in North American labour law, originated from the combination of statutes proscribing unfair labour practices with the decisions of the Alberta Court of Appeal regarding the "freedom of contract" of employers.

In its key 25-hour lockout decision, the Court had narrowly interpreted the notion of "bridging clauses," which extended the validity of a collective agreement to the period between its expiring date and the next agreement. The Court enabled employers to set new agreements, not unilaterally but with "individual employees." Unfair labour practices could not be evoked since "individual negotiation is not collective bargaining." $"$ In a seventy page ruling issued on October 28, 1986, the Alberta Labour Relations Board concluded this solution appeared to be acceptable:

We see nothing inconsistent in having implied individual contracts of employment co-exist with the union's exclusive authority to bargain on behalf of those employees... The scheme of the Labour Act is to grant collective bargaining rights, not to diminish the laws governing individual contracts of employment.

This logic, however, was not air-tight. It raised a final thorny question:

How does this common law option fit in a scheme that imposes an obligation to bargain in good faith, and an exclusive bargaining agency in favour of the certified union? ${ }^{93}$

There could only be one solution. The employer must make an offer in "good faith" but is not bound to reach an 
agreement. Even "if the union does not agree and the parties remain poles apart, the purpose of $s .139$ (fair collective bargaining) has been met and the employer suffers no restraint from that section." In other words, the employer could replace all of his workers and set new conditions "individually" with new employees, as long as an offer is made "in good faith" and the employer never mentions explicitly his intention of circumventing the union. This is what happened at Lakeside Industries. ${ }^{94}$

Rulings such as these have, to quote the AFL, "added a whole new dimension to the English language." They kept the legislative attack on unions veiled in the traditional concepts of industrial relations, providing Ian Reid and Don Getty with an elaborate legal doublespeak which was supposed to demonstrate the soundness of the labour laws and to guarantee the strikers would be treated fairly. Nobody was duped though: the "Change the Law" campaign, along with the strike, continued until late in the fall.

\section{Don Getty "leans on" Peter Pocklington Friday Decem-} ber 12, six-and-a-half months into the strike, Edmonton Journal columnist Linda Goyette, wrote that even though "the Tories [wanted] an amicable agreement at Gainers so badly their teeth hurt," such an outcome remained highly improbable. ${ }^{95}$ Later, the same day, to the surprise of the workers on the night shift picket line, an agreement was announced. The union held a closed-door meeting on Saturday to discuss the memorandum of agreement, and on Sunday 60.8 percent of the 846 union members who voted reluctantly approved the offer. The strike was over. ${ }^{96}$

Getty's intervention was instrumental in bringing the parties to the bargaining table and to an agreement. To justify his meetings with the parties and the pressure he applied when he "leaned on Pocklington," the Premier explained that he felt the strikers, "who have spent 20 or 30 years building that company," "had the right to go back" to their jobs. Getty also mentioned that "like most Albertans," he "was fed up by the length of time this took and the constant parade into court." 97 
These rationales cannot be taken seriously, for the government had let Gainers blatantly disregard the same "right to go back" for more than six months and continues to allow Lakeside and Zeidler Forest Industries to do the same on a permanent basis. In reality the government and the capitalist class were disturbed by the conflict and worried about its prolongation.

The first months of the strike were messy and generated substantial attention, but the Conservative government was left relatively unaffected. Opinion surveys conducted in June indicated that the strikers and their union were supported. The boycott they organized was upheld but the government itself was not blamed. ${ }^{98}$ By November, however, a majority agreed that "the main reason for the problems encountered in the Gainers-UFCW dispute [was] the out-dated labour laws." 99

Elections had just taken place and poor poll results did not threaten the government directly. Given the centrality of the Gainers strike in the public debates of the previous months, however, the Conservatives could not ignore such signals. In the May 1986 election they had lost most of their seats in Edmonton as well as three in Calgary, largely because many of their soft supporters abstained. 100 The Conservatives can stay in power without the Edmonton seats and can safely assume the Southern and rural voters will remain unaffected by the politics of industrial relations, ${ }^{101}$ but they cannot let their urban support evaporate. It was on this very support that Lougheed first established the party's ascendancy. In a province where the majority of the population is now urban, the loss of such support could have serious ramifications for the party. ${ }^{102}$ With issues like those raised in the "Boycott Gainers-Change the Law" campaign, the New Democrats, if they adopted a clear prolabour stance, could strengthen their already firm support among the Edmonton working class. From this base an outward expansion, like the one the Manitoba NDP realized in the $1960 \mathrm{~s}$, cannot be excluded, especially if small towns keep experiencing the union-busting tactics of contractors and resource-processing companies. ${ }^{103}$ The fall 1986 polls pointed in such a direction and confirmed the impression, 
shared at the time by many Conservatives, that the party's "grip" was "slipping."104

In any case, these opinion trends took on a more immediate significance at the end of November, when the Labour Legislation Review Committee began a series of public hearings, chaired by Labour Minister Ian Reid. ${ }^{105}$ These hearings, held across the province, raised issues much broader than the Gainers strike.

Typically, the representatives of business came to defend the status quo. The Edmonton Chamber of Commerce, for example, contended that Alberta's labour laws were "fundamentally sound" and that "changes should not be made to correct problems that don't exist." ${ }^{106}$ This argument, however, flew in the face of what everybody in Alberta had seen night after night on the television news: ordinary people engaged in violent, desperate fights, being beaten up and arrested by a police force equipped with riot gear and trained attack dogs.

By contrast, the unions' arguments appealed to the public's conventional idea of fairness. In Lethbridge, a member of the Alberta Teachers Association replied to the proposals of construction contractors who wanted the law changed to eliminate the very necessity of dealing with unions: "By your way, the only free part in free collective bargaining is that the employer is free to do whatever the hell he wants." The audience applauded. A Lakeside striker, Cathy Kennedy, made a moving presentation explaining how accepting 32 rollbacks had not been enough to satisfy the company.

After years of unsuccessful attempts to make the provincial labour laws a major political issue, this type of presentation, repeated daily on the local news, was a breakthrough for the labour movement. The testimony of Terence Day, an unemployed construction worker, brought the matter home. The local TV news showed a good portion of it, as the embarrassed 52 year old man broke into tears explaining how union-busting had made his family dependent on welfare for the first time in 37 years. ${ }^{108}$ Business leaders and Conservative politicians could not effectively counter the impact of such interventions. Action had become necessary. 
The Edmonton Chamber of Commerce mobilized its members. In a letter circulated on December 22, its president, Harold Banister, wrote:

...labour interest groups have overwhelmingly dominated the hearing process, resulting in the Review Committee's receipt of a skewed perception of labour relations reality in Alberta.... The Chamber representatives have advised me that we face the alarming possibility of having significant and extremely harmful legislative changes imposed on us within months. To avoid such a result, I am requesting each one of you to make at least one phone call to a member of the legislature sitting on one of the following four committees.... (emphasis added) ${ }^{109}$

Publicly, the Chamber of Commerce stated that "just because you hear the same things over and over again doesn't make it right." They used the classic argument, that investors would avoid a pro-labour province. ${ }^{110}$ Privately, they probably demanded a settlement at Gainers, the source of what was seen as an "alarming" political threat. Ian Reid denied there was any relation between the work of his committee and Getty's intervention in the dispute. But as columnist Linda Goyette remarked, "the Gainers dispute [haunted] the Reid Committee" because it provided "naked evidence that the current labour distress" had "something to do with shoddy legislation." 111 The leaders of a worried capitalist class reacted and pressured the government to intervene and end the strike. The interests of one had to give way for the good of all.

At first, Pocklington resisted. Getty came out of a December 5 meeting saying that the owner of Gainers "had difficulty with" the idea of taking the strikers back. ${ }^{112}$ Apparently, Getty asked Pocklington to consider the greater Tory good, which was being harmed by his actions. He also "informed" Gainers about a federal-provincial program that could provide financial assistance for capital expansion. ${ }^{113}$ Pocklington finally conceded.

Ultimately, he had no choice. The boycott had seriously hurt Gainers and, more importantly, the company had not made intelligent use of the pro-business labour laws. As explained above, the law stipulates that a union can be destroyed, but only if it is done in "good faith." To remain 
legitimate, an employer must never explicitly mention that he is attacking the union. Pocklington's error lay in the fact that he had flaunted his intentions.

From the very beginning, he publicly expressed his aims, to the surprise of businessmen who did not understand why he was so openly looking for trouble. ${ }^{114}$ It could be suggested that most of the owner's declarations were made during television and radio interviews, perhaps on the spur of the moment. The company's strategy, however, was also too obvious. Gainers made no formal proposal to the union until June 13, more than two weeks into the strike and only "on the intense urgings of the Deputy Minister of Labour." The Labour Relations Board could not avoid concluding that Gainers had failed to bargain in good faith: "negotiating with a party that refuses to reveal an opening position becomes, to use the popular phrase, 'like nailing jelly to the wall'." The Board also determined that, in spite of the employer's ownership and control of any surplus from the employees' pension plan, Gainers' secret termination of the plan constituted an unfair practice. ${ }^{115}$ The Board imposed a December 1 deadline for a complete written proposal, and the directive was upheld by the Court of Queen's Bench, even though the Board's pension plan decision was quashed. ${ }^{116}$ As explained above, the December 1 offer was itself controversial, leading to further legal battles.

Since Gainers had been caught bargaining in bad faith, its effort to destroy the union was probably doomed. Not that the union could win decisively through the courts. As Bryan Palmer notes, the labour movement "has never yet won any lasting or important gains through the "proper channels' - after all, that is not what they are created for." Alberta courts, in particular, could not be trusted; they had refused to uphold a Labour Relations Board decision against Zeidler Forest Products on the grounds that the company had had good relations with its employees for more than fifty years. ${ }^{117}$ Yet, Gainers' troubles with the law were going to last, and this spelled trouble for business and politicians. This is apparently what Getty told Pocklington, warning him "in tough language that he couldn't continue to break the law and bargain in bad faith." 
One wonders how Gainers, with its team of legal experts, could blunder so obviously in its attempt to break the union. The ambiguity of the law, only clarified in October by the ruling of the Labour Relations Board, may explain some of the mistakes. The fact that Gainers had an American president who was used to "right-to-work" states may also have played a role. Pocklington is also notorious for his brashness. During the strike he took actions to terminate his employees' pension plan without even informing Phil Ponting, chief spokesman for Gainers in the negotiations. ${ }^{119}$ More simply, the conflict reflected the supreme confidence of a member of a seldom challenged capitalist class, who simply assumed he would have it his own way. The economic and political counter-offensive mounted by the labour movement came as a surprise.

6. Victory or Defeat? The agreement was highly controversial. It allowed the workers to keep their jobs and their union, but it meant wages far short of parity with the rest of the industry. Wages were frozen for 1987 and 1988 and were to increase by a mere three percent in 1989 and 1990, less than what the Disputes Inquiry Board of Alex Dubensky recommended in July, when a large majority of the union local rejected wage increases below parity.

Many strikers were bitterly disappointed and tore up their copy of the proposal. Renee Pevvy, machine operator at Gainers, summed up the general feeling:

We're screwed for the next four years. We got nothing. We paid $\$ 10$ million to Pocklington [a pension plan concession] to get him to let us go back to work. He's laughing all the way to the bank. We had the support of the whole Canadian labour movement and we let them down. ${ }^{120}$

Others, like Deborah Gunville, agreed that the settlement was "nothing to jump up and down about" but felt little more was possible. After six-and-a-half months, and with Christmas close at hand, the cost of pursuing the strike had begun to take its toll on the strikers. The agreement was accepted by 60.8 percent of those who voted. 121 
Although the strikers' decision was understandable under difficult circumstances, those rejecting the agreement correctly assessed its broader implications. Of the two core principles that have constituted the foundations of the Canadian industrial relations framework since the 1940srecognition of unions and pattern bargaining-only one was salvaged, recognition. Indirectly, even that principle was undermined by the concessions; as one of the strikers put it, "if that's all we get after six months, we don't need a union." 122

As for the labour laws, no gains were made. On the contrary, in the summer of 1988, after two years of deliberations, the government adopted laws that weakened the position of labour. The new Labour Relations Code is built on the premise "that lawful strikes or lockouts represent failures of the system" and assumes "that if a sufficient number of roadblocks are placed along the road to lawful work stoppages, the underlying conflicting interests and issues in dispute will be resolved." ${ }^{23}$ A mandatory 14-day cooling off period is imposed, for instance, before any work stoppage. In its submission on the Bill, the Alberta Trade Unions' Lawyers Association concluded that "industrial peace through coercion appears to be the higher public policy goal." "The focus of this legislation" wrote the association "is postponement of disputes pending third party intervention, not union recognition and freedom of association." 124

The new Code gives the cabinet the power to decertify unions that conduct illegal strikes, and, probably in violation of the Charter of Rights and Freedoms, allows the Labour Relations Board to limit picketing. ${ }^{125}$ Furthermore, it erects new barriers against certification. On one hand, the new Labour Relations Code requires a certification vote in all instances, even when all the workers of a company sign union cards. On the other hand, it "removes the Labour Relations Board's right to certify a union if it finds management has interfered with an organizing drive," thereby guaranteeing unfair practices used to "win" elections will go unpunished. ${ }^{126}$ After British Columbia, which adopted similar measures in 1984, Alberta becomes the second 
Canadian jurisdiction to shift toward the American certification model, a model, that according to most experts has contributed to the decline of American unions. With this model, it becomes easy for corporations to hire "consultants" who can "manage" a certification vote and guarantee a "victory." 127

Bitter concessions and regressive labour legislation do not exactly constitute the stuff of victories. Even the October 1989 takeover of Gainers by the Alberta government, greeted with a standing ovation by the workers, does not guarantee improvements. Yet there is a silver lining to the Gainers strike. To see it, it is necessary to look beyond the immediate circumstances of the conflict and consider the politics of industrial relations in Alberta and in the rest of North America.

The entire North American labour movement is on the defensive. In the United States, the postwar industrial relations framework has gradually been emptied of its content and the trade unions have gone from defeat to defeat. For Canadian capitalists, the temptation to march in the footsteps of the Americans is great, but a major precedent has yet to be set. Canada has not yet experienced anything on the scale of Reagan's firing of the air traffic controllers or of the United Auto Workers' concessions to Chrysler, the two events that set the trend south of the border. In this regard, the Gainers strike held considerable potential. First, it occurred in an industry central to the postwar rise of industrial unionism and to its recent defeat in the United States, an industry already challenged by aggressive corporate bargaining. Second, it involved a strongly committed employer willing to pay the price required to make union busting history. Third, it took place in what was thought to be a hostile environment for Canadian labour, a conservative province with a government as pro-business and antilabour as any. Against these odds, the labour movement accomplished much because it stood united and determined behind the strikers.

The importance of unity and militancy, even in defeat, is apparent when the case of Gainers is compared to its American equivalent, the Hormel strike. This strike has been 
called "a monument to union impotence" by the Washington Post. ${ }^{128}$ It involved meatpacking workers who lost their fight against concessions largely because they were abandoned, and later opposed, by their federation, the Minnesota AFL-CIO, and by their international union, the UFCW. ${ }^{129}$ Rod Huinken, a representative of the Hormel strikers who visited Edmonton in December 1986, was surprised by the support the Gainers' workers had received, and even more so by the financial and technical assistance the local had obtained from the same international, the UFCW. ${ }^{130}$

The international claims the difference between the Gainers and the Hormel strikes is a proof of its new militancy. Many unionists doubt this is true and refer to the numerous complaints members still have against a union which fears activism. ${ }^{131}$ More likely, the UFCW backed its Edmonton local because it had no choice. According to Jim Selby, the AFL's communications director, the provincial and national labour movements were committed so early and so strongly to the Gainers strike that the UFCW could not avoid supporting it. ${ }^{132}$ The Canadian political context, which is less open to right-wing ideology, probably also played a role. The Gainers strike showed that the overall balance of class forces that distinguishes Canada from the United States remains relevant, even in Alberta.

Alberta workers needed an issue like the Gainers strike to revitalize their movement. The conflict also accelerated a transition in provincial politics that the May 1986 election first made visible. As Finkel notes, "years of reactionary provincial administration and labour timidity in opposing governments and employers head-on [will] not be so easily swept aside." 133 The strike nevertheless increased the legitimacy of labour and brought labour issues to the forefront of the political scene. A recent study finds that the public support for unions and the willingness to join a union have increased in Edmonton. Levels of support are significantly higher than in Winnipeg, which used to be the more pro-union of the two cities. ${ }^{134}$ The contrast between the nurses' strikes of 1977 and 1982, when strikers were widely blamed, and the successful and well supported strike of 1988 shows the significance of these trends. ${ }^{135}$ 
The Getty government has recovered to some extent from two years of difficulties. ${ }^{136}$ Nevertheless, changes to the labour laws remained at the forefront of discussion for most of 1988 and, to avoid debates, the Conservatives had to invoke closure for every reading of the two labour bills, "six times in all, a total unprecedented in any other Canadian legislature." 137 Likewise, the control the government inadvertently obtained over Gainers guarantees that the situation of its workers will continue to have a high political profile. The scope of Alberta politics has certainly broadened.

For the Canadian labour movement as a whole, the Gainers strike may also represent a landmark, as a proof of unity and determination against attacks on unionism and as a demonstration that the use of strikebreakers is neither acceptable nor effective. In June and July 1987, the Mulroney government had to retreat when the postal workers defeated an attempt to operate with strikebreakers and to obtain concessions. In a perceptive editorial, the Globe and Mail concluded that the use of strikebreakers had not only failed but had endangered what it saw as a laudable goal, the reform of Post Office work rules. Referring to Gainers, the Globe and Mail said that public opinion could not be ignored. The use of a broadly repudiated strategy only undermined the push for concessions. In July, after the settlement, a similar conclusion was reached by the industrial relations editorialist of Le Devoir; Canada Post had failed because it had used a tactic already discredited at Gainers in Edmonton. ${ }^{138}$ Nothing has been definitively won, as the strike of the inside postal workers has shown, but these mainstream assessments of strikebreaking confirm the national legacy left by the struggle at Gainers.

7. Conclusion Many of the struggles remembered as central to the history of Canadian workers were defeats in the short term: Kirkland Lake (1942), Asbestos (1949), Murdochville (1957), and United Aircraft (1974-75), for example, were all strikes that ended with losses or meagre gains for those involved. In the end, however, a rekindled rank and file militancy, a stronger labour movement, and a clear political stance contributed to bring about progressive changes. ${ }^{139}$ 
Obviously, parallels with the past should not be overdrawn. The present conflicts are mostly defensive and the losses like wage parity for the Gainers employees - are definite steps backwards. Supported by conservative governments, the corporate offensive continues to register victories. ${ }^{140}$ Serious challenges have been launched in every province. The difficulty of meeting such challenges is compounded by the unions' structural weaknesses and by their lack of a clear positive project.

First, short of busting unions openly, employers have the capacity to circumvent them. This strategy is common in the American meatpacking industry, where old plants are simply replaced by new rural plants that are capital intensive and non-unionized. Waging a war against the unions is not necessary when they can be smoothly eliminated by what Mike Davis calls a coup d'etat. Such tactics have already been introduced in Canada, by Canada Packers as well as Gainers. ${ }^{141}$

In the $1980 \mathrm{~s}$, the unions are also vulnerable because of their inability to organize a growing segment of the population that either works in services, is employed on a part-time or temporary basis, or is unemployed. In the last decade, the proportion of part-time workers alone has jumped from 11.1 to 15.6 percent of the total workforce, most of the increase coming from low-paid service jobs, which workers accept because of the lack of full-time positions. ${ }^{142}$ In Quebec, where union membership is the highest in Canada, there are more heads of family on welfare or unemployed than there are members in the three major union federations. ${ }^{143}$ Whether the labour movement can reach these people remains an open question.

Finally, the United States no longer provides the model for Canada's unions. In the 1940s, the rise of the CIO and the legislative gains obtained by the American unions inspired Canadian workers to establish industrial unions and to fight for changes on their own. In a highly integrated continental economy, the strength of the American unions also stabilized the postwar settlement reached in Canada. Today the American unions are crushed and caught in a vicious circle of competitive concessions. American rank- 
and-file movements are already looking north of the border for inspiration, to unions that are more political, less conservative, and less willing to accept concessions. ${ }^{144}$ But they have a long way to go in order to reconstruct their unions and in this they are handicapped by the absence of an established political party of the left.

The current situation of the labour movement in both Canada and the United States leaves little room for optimism. But workers are not condemned to passivity. The struggle at Gainers has enabled many to stand up for their rights, it has left the provincial and national labour movements stronger, and it has contributed, at least minimally, to a change in Alberta politics.

As many authors have noted, trade unions have yet to produce a positive alternative to the mere defence of the status quo. ${ }^{45}$ At the very least, conflicts like the Gainers strike force them to build links with other groups, to encourage community organizing, to raise new issues, and to become more political. While no more than first steps toward renewal, these actions are necessary. ${ }^{146}$

In the long run, the Gainers strike may be remembered as just one among numerous important conflicts. For the time being, however, it has once again shown that union militancy and politics matter. Together they provide the only genuine alternative to the current corporate offensive.

\section{Notes}

We thank Caroline Andrew, Dan Backs, Manfred Bienefield, Tom Enders, Anne Forrest, Doug Kerr, Graham Lowe, Jack Masson, Joel Novek, Leo Panitch, Larry Pratt, Yonatan Reshef, James C. Robb, Jim Selby, Donald Swartz, Allan Tupper and George Warskett for their help.

1. G.S. Kealey, "1919: The Canadian Labour Revolt," in B.D. Palmer, ed., The Character of the Class Struggle: Essays in Canadian Working-Class History (Toronto: 1986), p. 111; J.E. Cronin, "Labor Insurgency and Class Formation: Comparative Perspectives on the Crisis of 1917-1920 in Europe," and D. Montgomery, "New Tendencies in Union Struggles and Strategies in Europe and the United States, 1916-1922," in J.E. Cronin and C. Sirianni, eds., Work, Community, and Power: The Experience of Labor in Europe and America, 1900-1925 (Philadelphia: 1983). 
2. W. Caragata, Alberta Labour: A Heritage Untold (Toronto: 1979), pp. 86-9. The Amalgamated rested on weak foundations because it had organized the industry on customary jurisdictional lines, that is according to skills and crafts. At the time of the Edmonton strike, the international was "impoverished, led by divided and untried officers, and weakened by internal dissension." In the following year, it simply abandoned all Canadian activities. D. Brody, The Butcher Workmen: A Study of Unionization (Cambridge: 1964), pp. 95 and 103; J.T. Montague, Trade Unionism in the Canadian Meat Packing Industry (Ph.D. Thesis, University of Toronto: 1950), 38.

3. Brody, Butcher Workmen... pp. 152-62; Caragata, Alberta Labour... pp. 101-2; A. Finkel, "The Rise and Fall of the Labour Party in Alberta, 1917-42," Labour/Le Travail 16 (Fall 1985), p. 90.

4. Caragata, Alberta Labour... pp. 127-32; B. Mahn and R. Schaffner, "The Packinghouse Workers in Kitchener: 1940-47," in T. Copp, ed. Industrial Unionism in Kitchener, 1937-47 (Elora, Ontario: 1976), pp. 41-9. In June 1953, the UPWA and the Amalgamated (AFL) signed a formal cooperation agreement. The AFL and the ClO merged in 1955, and were followed in 1956 by their Canadian-the TLC and the CCL-and Albertan counterparts-the Alberta Federation of Labour and the Industrial Federation of Labour. The UPWA and the Amalgamated did not merge until 1968. Later, in June 1979, the Amalgamated and the Retail Clerks International Union formed the current United Food and Commercial Workers (UFCW). Brody, Butcher Workmen... p. 239; Caragata, Alberta Labour... p. 142; Monthly Labour Review 102:9 (September 1979), p. 56.

5. Montague, Trade Unionism in the Canadian Meat Packing Industry; Globe and Mail 20 December 1986, p. D2.

6. M. Davis, Prisoners of the American Dream (London: 1986), pp. 142-6; Globe and Mail 28 January 1987, p. B12.

7. C. Huxley, D. Kettler and J. Struthers, "Is Canada's Experience 'Especially Instructive'?," in S.M. Lipset, ed., Unions in Transition (San Francisco: 1986); C. Gonick, The Great Economic Debate (Toronto: 1987), pp. 345-9.

8. La Presse 27 December 1986, p. H1.

9. Shirley Carr, quoted in Maclean's 13 July 1987, p. 30.

10. See for instance: Y. Reshef, "Union Decline: A View from Canada," Working Paper, Faculty of Business, University of Alberta, 1988; J. Richards, "Labour Relations in Western Canada," Paper presented at the London Conference for Canadian Studies, 25-27 November 1987.

11. M. Link, "Free Trade and the Forced Harmonization of Labour Law," Canadian Dimension July/August 1988.

12. L. Panitch and D. Swartz present a similar point of view in The Assault on Trade Union Freedoms: From Consent to Coercion Revisited (Toronto: 1988), pp. 99 and 111.

13. A. Finkel, "The Cold War, Alberta Labour, and the Social Credit Regime," Labour/Le Travail 21 (Spring 1988), p. 151.

14. J. Richards, "Labour Relations in Western Canada."

15. Panitch and Swartz, The Assault on Trade Union Freedoms p. 82. 
16. J. Calvert, "The Divergent Paths of Canadian and American Labor," in M. Davis and M. Sprinker, eds., Reshaping the US Left: Popular Struggles in the 1980s (Volume 3 of The Year Left) (London: 1988).

17. Canadian Meat Council, Canada's Meat Processing Industry: Background Information (Islington, Ontario, June 1984); W.A. Kerr, "The Changing Economics of the Western Livestock Industry," Canadian Public Policy 11 (July 1985), p. 294. Statistics Canada has slightly different numbers for Alberta in 1981, but the ranking is the same (4,403 "production workers" rather than 5,500 "employees"; $\$ 1,816,153,000$ rather than $\$ 1.8$ billion in sales). By 1985 , the ranks had not changed. Statistics Canada, Manufacturing Industries of Canada: National and Provincial Areas (31-203), 1981, p. 151 and 1985 , p. 201.

18. "The active suppression of competition in the meat-packing industry is a matter of public record." A. Forrest, "The Rise and Fall of National Bargaining in the Canadian Meat-packing Industry," Relations industrielles 44:2 (1989), p. 401.

19. H. Fredeen, The Competitive Position of the Canadian Pork Industry Agriculture Canada (October 1977), Appendix D.

20. V. Stock, president of Canada Packers Inc., quoted in Globe and Mail 28 May 1983, p. B1.

21. J. C. Gilson and R. Saint-Louis, Policy Issues and Alternatives Facing the Canadian Hog Industry Study prepared for Agriculture Canada and the Canadian Pork Council (Ottawa: 1986), p. 16.

22. J. Novek, "Peripheralizing Core Labour Markets?: The Case of the Canadian Meat Packing Industry," Work, Employment and Society 3 (June 1989), pp. 168-72.

23. E. Wilson, "Labour and Consumer Relations," in Proceedings 64th Annual Conference of the Canadian Meat Council (Quebec, 2-3 February 1984), p. 11-2.

24. Davis, Prisoners p. 217.

25. From 1972 to 1982 , American wages were higher than Canadian wages. For this new view of wages, see: D.M. Adams, "General Manager's Address," in Proceedings p. 7-3; C. Lanoix, "Competitive Position of the Canadian Meat Packing and Processing Industry," Food Market Commentary 6 (December 1984), pp. 40-42; W.A. Kerr and S.M. Ulmer, The Importance of the Livestock and Meat Processing Industries to Western Growth Discussion Paper no. 255, Economic Council of Canada (Ottawa, March 1984), p. 40.

26. Forrest, "The Rise and Fall of National Bargaining," p. 403.

27. Y. Jacques, "Export Strategies for Canadian Hogs and Pork," in Proceedings of the National Workshop on Hog Marketing Alternatives Agriculture Canada and Canadian Pork Council, Ottawa, 26-7 February 1987, p. 41.

28. Gilson and Saint-Louis, Policy Issues pp. 32-3. In trade disputes, Canadian producers also refer to the American consumers' demand for the leaner Canadian pork. Edmonton Journal 6 October 1988, p. D3. 
29. Gilson and Saint-Louis, Policy Issues p. 16; W. A. Kerr, S. E. Cullen, M. F. Sommerville, Trade Barriers and the Western Canadian Livestock Industry Working Paper 11/86, Agriculture Canada (Ottawa: 1986), p. 59.

30. W.A. Kerr, S.E. Cullen, M.F. Sommerville, Trade Barriers pp. 83 and 148-9; J.C. Gilson and R. Saint-Louis, Policy Issues 22; Edmonton Journal 27 June 1987, p. C20. Canadian pork producers are likely to be the first group to challenge American trade measures before the free-trade binational panel. Edmonton Journal 18 February 1989, p. C2.

31. Forrest, "The Rise and Fall of National Bargaining," 399-404; Novek, "Peripheralizing," pp. 163-7.

32. Globe and Mail 17 May 1982, A1; Forrest, "The Rise and Fall of National Bargaining," pp. 394-405.

33. A. Lipietz, Mirages et miracles: Problemes de l'industrialisation dans le tiers monde (Paris: 1985), pp. 140-4; Investment Dealers Association of Canada, Alberta Economic Outlook (Toronto, November 1983), p. 2.

34. D. Bellemare and L. Poulin-Simon, Le défi du ple in emploi (Montréal: 1986), p. 199. As David Milne notes, the National Energy Program constituted "a convenient straw man for this downturn" and businessmen and Conservatives "made the most political mileage they could of it." A recent study supports Milne's argument: "For all the attention that has been focussed on them, Canadian policies influenced only the timing of the impact of world prices on Canadian prices, so that the changes in world prices and trade conditions remained the fundamental influences on the activity of the oil and gas industry and on the pattem and size of Canadian energy demand." J. F. Helliwell, M. E. MacGregor, R. N. McRae, and A. Plourde, Oil and Gas in Canada: The Effects of Domestic Policies and World Events Canadian Tax Paper No. 83 (Toronto: Canadian Tax Foundation: 1989), p. 228; D. Milne, Tug of War: Ottawa and the Provinces Under Trudeau and Mulroney (Toronto: 1986), pp. 96-7.

35. Alberta Bureau of Statistics, Alberta Statistical Review First Quarter, 1987 (Edmonton, June 1987), p. 26.

36. This statement assumed erroneously that Alberta's recession was due to high wages. At the same time, unemployment was declared healthy by Alberta's Manpower minister, Emest Isley, who saw it as a good way to control wage levels and productivity. These statements are in: Government of Alberta, White Paper: Proposals for an Industrial Strategy for Albertans, 1985 to 1990 (Edmonton, July 1984), p. 47; Edmonton Journal 11 February 1986; R. D. White, Law, Capitalism and the Right to Work (Toronto: 1986), p. 64. On the anti-union measures taken by the Alberta government see Panitch and Swartz, The Assault on Trade Union Freedoms pp. 43-4 and 80-2.

37. Globe and Mail 15 October 1984, B5. Although the industry is dominated by national or regional firms, which have many plants, many single-plant firms control medium to large-scale plants. Lakeside is one of those. Agriculture Canada. The Development of an Investment Planning Tool for the Meat Packing, Processing and 
Distribution Industry Economic Working Paper (March 1984), pp. 43-5.

38. Maclean's 29 December 1986, 8; Edmonton Journal 21 November 1987, p. A4.

39. On Bolanes: Edmonton Journal 10 June 1986, p. C8.

40. Edmonton Journal 5 July 1984, pp. A1-A2; and 6 July 1984, B1; Globe and Mail, 5 July 1984, p. B4; Alberta Report 16 June 1986, p. 18; E.E. Seymour, "They Can't Jail the Strike," Canadian Labour October 1986, p. 16.

41. B. Johnstone, "Interview: Alberta Labour at the Crossroads," Athabasca University Magazine Special Labour Supplement, 10:5 (May 1987), pp. 19-20.

42. Edmonton Journal 7 July 1984, p. B1; and 13 July 1984, p. B2; Calgary Herald 13 July 1984, p. B5.

43. Edmonton Journal 14 July 1984, p. B1; Seymour, "Can't Jail the Strike," p. 16.

44. Canada Packers Inc. and Burns Food are the two largest firms in Canada (Gainers Inc. is third). Lanoix, "Competitive Position," 41. For the ranking of the firms: Agriculture Canada, Development of an Investment Planning Tool pp. 43-5.

45. Edmonton Journal 14 July 1984, B1; Globe and Mail 14 July 1984, p. A2.

46. Forrest, "The Rise and Fall of National Bargaining," p. 396.

47. J. Selby, "Pigs and Packing Houses: Peter Pocklington, the Police and the Gainers" Strike," Canadian Dimension (September/October 1986), pp. 4-6. Although it failed to destroy the Alberta Pork Producers Marketing Board, which sets the price for hogs, Gainers took advantage of the depressed market left by the rationalization of the industry in the province. With only two buyers left, Gainers and Fletcher's (owned by the Board), the price went down. Globe and Mail, 22 October 1984, B3; Alberta Report 16 June 1986, pp. 18-19.

48. Pocklington has also been trying to break the union at his recently acquired Oakland plant. Edmonton Journal 10 June 1986, p. C8.

49. Bob Clipperton, the only alderman on the city council to oppose the incentives plan, estimates that with the provincial contribution, it amounts to giving $\$ 5$ million of taxpayers' money for a plant that cost $\$ 6$ million to build and equip. In the region, many were angry about the deal. It contributed to the electoral defeat of the local MLA, a Conservative cabinet minister. T. Pugh, "North Battleford's Gainers Plants: Sweet or Sour Pork?," Canadian Dimension (May/June 1987), 13-15: Edmonton.Journal 22 October 1986, p. B3.

50. Alberta Report 16 June 1986, p. 19.

51. Johnstone, "Interview," p. 20.

52. Calgary Herald 19 June 1986.

53. A spokesman for Canada Packers suggested that Pocklington was "a little extreme" with his wage figures and the president of Intercontinental Packers, a Saskatoon firm, criticized Pocklington's assertion that he could not pay the industry wages: "I just don't understand 
if we can afford it how he can't." Edmonton Journal 7 June 1986, p. B3; 11 June 1986, p. E16.

54. Seymour, "Can't Jail the Strike," p. 16; Alberta Democrat (NDP Newsletter), August 1986, p. 18; Alberta Report 9 June 1986, p. 20; Edmonton Journal 20 June 1984, p. B4.

55. Alberta Report 30 June 1986, p. 21.

56. Edmonton Journal 6 June 1986, p. F10.

57. A. Nikiforuk, "The War on 66th Street," in A. Nikiforuk, S. Pratt, and D. Wanagas, eds., Running on Empty: Alberta After the Boom (Edmonton: 1987), p. 130; Alberta Report 10 August, 1987, p. 18.

58. In the fall of 1988, Fletcher's demanded concessions to match those obtained by Gainers in 1986. A $71 / 2$ month lockout ended with concessions in March 1989. Gainers, on the other hand, paid for its gamble. Until the Alberta government seized the company in October 1989 , it remained plagued by a "very low worker morale" and by an informal consumer boycott (which was reinforced when Peter Pocklington sold Wayne Gretzky to the Los Angeles Kings). Alberta Report 27 March 1989, pp. 30-31; Globe and Mail 9 October 1989, p. A5; and 11 October 1989, pp. A1 and B1. The discussion on capitalist actions borrows elements from: C. Offe and $\mathrm{H}$. Wiesenthal, "Two Logics of Collective Action: Theoretical Notes on Social Class and Organizational Form," Political Power and Social Theory 1 (1980); D. Vogel, "Why Businessmen Distrust Their State: The Political Consciousness of American Corporate Executives," British Journal of Political Science 8 (January 1978); and W. Streeck, "The Uncertainties of Management in the Management of Uncertainty," International Journal of Political Economy 17 (Fall 1987), p. 59.

59. Johnstone, "Interview," p. 20.

60. Edmonion Journal 1 June 1986, p. A1; and 4 June 1986, p. A3; Seymour, "Can't Jail," p. 17.

61. Edmonton Journal 11 June 1986, pp. A1 and E16; Seymour, "Can't Jail," p. 16.

62. Ibid.

63. James C. Robb, letter to the authors, September 1988. In editorial, the Edmonton Journal talked of "injunctions that evoke the police state.... The sort of tight-fisted control one associates with the Polish regime in dealing with Solidarity...."; 12 June 1986, p. A6.

64. Edmonton Journal 11 June 1986, p. E16.

65. By the end of the strike, $\$ 500,000$ had been spent on police overtime, and more than 600 people had been arrested. Edmonton Journal 16 December 1986, p. A1; Globe and Mail 15 December 1986, p. A1. See also: Seymour, "Can't Jail," 16; Selby, "Pigs and Packing Houses," pp. 4-6; Alberta Report 16 June 1986, p. 16; 28 July 1986, p. 28; and 6 October 1986, pp. 20-22.

66. Edmonton Journal 22 November 1986, B1 and 2 December 1986, p. B1.

67. Globe and Mail 12 June 1986, p. A5; Edmonton Journal 11 July 1986, p. A1.

68. Alberta Report 6 October 1986, pp. 20-21. 
69. Globe and Mail 20 December 1986, p. D2.

70. Edmonton Journal 12 June 1986, p. A6.

71. Edmonton Journal 3 June 1986, p. B3; 5 June 1986, p. D2; 7 June 1986, p. B1. In a recent letter to the Edmonton Journal Nick Taylor, leader of the Liberal Party, explained his party's viewpoint: "The Liberal caucus toes neither the 'AFL' line nor the "pro-business' line" but is instead interested in seeking a compromise. Good legislation is never comprised of absolutes-it must strike a careful balance if it is to be fair and acceptable." 13 June 1987, p. A7 (italics in original).

72. A. Tupper, "Opportunity and Constraint: Grant Notley and the Modem State," and G. Stevenson, "Class and Class Politics in Alberta," in L. Pratt, ed., Social ism and Democracy in Alberta (Edmonton: 1986).

73. Alberta Hansard 10 July 1986, p. 473; "A former steam and gaspipefitter, Strong is the full-time business manager and chief negotiator of the 3,000-strong Edmonton Plumbers Local 488, one of the biggest construction union locals in the province." Calgary Herald 16 June 1986. See also, for ND comments: Edmonton Journal 3 June 1986, p. B3; and 7 June 1986, pp. A1 and B1.

74. Ray Martin, the ND leader, talked of "Alabama labor laws." The other countries were evoked more indirectly by critics who wanted to underline the effects of Alberta's "barbaric" laws. Edmonton Journal 5 June 1986, p. D2; 7 June 1986, pp. B1 and B5; 10 June 1986, p. Al.

75. Edmonton Journal 13 June 1986, p. A1; Alberta Democrat August 1986, p. 20.

76. This argument borrows some ideas from: T. Skocpol, "Political Response to Capitalist Crisis: Neo-Marxist Theories of the State and the Case of the New Deal," Politics and Society 10 (1980); and J. Brodie and J. Jenson, Crisis, Challenge and Change: Party and Class in Canada (Toronto: 1980).

77. The second quote is from Clint Mellors, deputy labour minister. $E d$ monton Journal 3 June 1986, p. B3; and 4 June 1986, p. A3.

78. Edmonton Journal 5 June 1986, p. D2.

79. The preliminary draft of the speech did not mention labour laws. The AFL pushed the government into tagging on another sentence. Don Aitken, Public presentation, University of Alberta, Fall 1986. See also: Alberta Labour, Final Report of the Labour Legislation Review Committee (Edmonton; February 1987), p. 65; Alberta Federation of Labour, Submission to the Labour Legislation Review Committee of the Government of Alberta (Edmonton: 12 December 1986), p. 2; Alberta Hansard 12 June 1986, p. 5; Edmonton Journal 3 June 1986, p. B3.

80. Alberta Hansard 10 July 1986, p. 476.

81. See: Alberta Federation of Labour, Labour Law Bulletin number 1 (not dated; Fall 1986), p. 5; Panitch and Swartz, The Assault on Trade Union Freedoms.

82. Johnstone, "Interview," p. 18. 
83. The uniqueness of Alberta can easily be exaggerated. Garth Stevenson, for instance, simplifies when he writes that the province remains "prisoner of its past." G. Stevenson, "Quasi-Democracy in Alberta," in H. G. Thorburn, ed. Party Politics in Canada Fifth edition (Scarborough, 1985), p. 280.

84. Unionized projects passed from over $70 \%$ of the total in $1976-82$ to less than 10 percent in late 1984, and wages dropped by up to 38 percent between 1982 and 1984. This attack on unions, combined with the lack of activity in a depressed economy, led a large number of skilled workers to leave the province. Already, contractors have difficulties finding bricklayers, and other shortages are foreseen. E.G. Fisher and S. Kushner, "Alberta's Construction Labour Relations During the Recent Downturn," Relations industrielles 41:4 (1986), p. 778; Globe and Mail 19 December 1986, p. B4.

85. These conflicts all occurred in remote towns. Reg Basken, National Director of the Energy and Chemical Workers Union explained that although similar to the Gainers strike, the conflict at Suncor had the disadvantage of taking place 300 miles from the nearest television station. Reg Basken, Interview, 16 July 1987; Calgary Herald 18 May 1986, p. B5; Edmonton Journal 14 October 1986, p. A11; 11 April 1987, pp. A2 and B4; 18 June 1987, p. E2; 14 August 1987, p. B5; 9 July 1989, p. A3.

86. Alberta Report 16 June 1986, pp. 18-20.

87. See K. Moody, "Reagan, the Business Agenda and the Collapse of Labour," Socialist Register 1987, p. 159.

88. Offe and Wiesenthal, "Two Logics of Collective Action."

89. J.K. Masson and P. Blaikie, "Labour Politics in Alberta," in C. Caldarola, ed., Society and Politics in Alberto (Toronto: 1979), p. 282.

90. Daily Herald Tribune (Camrose), 29 November 1983.

91. Finkel, "Cold War, Alberta Labour, and Social Credit," pp. 149-51; Edmonton Journal 9 November 1988, p. B1; and 14 November 1988 , p. B1.

92. United Food and Commercial Workers International Union Local 280-P. v. Gainers Inc. Alberta Labour Relations Board, File L.R. 302-G-1 (28 October 1986), pp. 570-1.

93. Ibid. pp. 573-5.

94. In both the United States and Canada, the recognition principle and the duty to bargain in good faith do not imply a duty to reach an agreement since the latter would deny the "freedom of contract." The conciliation of these duties and freedoms has been a thorny issue for lawyers and experts. In the United States, where the issue generated more conflicts, the "freedom of contract" has predominated. The right not to agree was explicitly stated in section 8(d) of the Taft-Hartley Act of 1947 and was reaffirmed when the Labor Law Reform Act of 1977 was defeated. As a result, up to a third of newly certified unions never sign a contract. M. Bendel, “A Rational Process of Persuasion: Good Faith Bargaining in Ontario," University of Toronto Law Journal 30 (1980), Pp. 13-14; C. Backhouse, "The Fleck Strike: A Case Study in the Need for First Contract Arbitration," Osgoode Hall Law Journal 18 (December 1980), pp. 527-29; R. B. 
Freeman and J. L. Medoff, What Do Unions Do? (New York: 1984), pp. 239-40. In Canada by contrast, "our labour relations system has always paid lip service to freedom of contract" and recent reforms have favoured a strong interpretation of the principle of good faith bargaining. Hence, the Alberta Labour Relations Board's interpretation, which leaves the concept of good faith bargaining without content, goes against the usual Canadian practices. Bendel, "A Rational Process..." p. 14; Huxley, Kettler and Struthers, "Is Canada's Experience 'Especially Instructive'?" p. 131; P. Weiler, "Promises to Keep: Securing Workers' Right to Self-Organization Under the NLRA," Harvard Law Review 96 (June 1983), p. 1821.

95. Edmonton Journal 12 December 1986, p. A7.

96. Edmonton Journal 13 December 1986, pp. A1 and F8; 14 December 1986, p. A1; 15 December 1986, p. A1; Maclean's 29 December 1986, p.8.

97. Edmonton Journal 13 December 1986, p. F8; Globe and Mail 16 December 1986, p. A2.

98. Edmonton Journal 6 June 1986, p. A1; Edmonton Journal 26 June 1986, p. A1.

99. Edmonton Journal 20 November 1986, p. B1.

100. A. Tupper, "New Dimensions of Alberta Politics," Queen's Quarterly 93 (Winter 1986).

101. If anything, farmers have a tendency to side against trade unions. In the summer of 1986 , many were ready to act as strikebreakers during the conflicts involving the workers of Fletcher's in Red Deer and the grain-handlers in Thunder Bay. Alberta Report 9 June 1986, pp. 19-20 and Winnipeg Free Press 30 September 1986, p. 50.

102. J. Richards and L. Pratt, Prairie Capitalism (Toronto: 1979), p. 166.

103. Garth Stevenson demonstrates eloquently the plausibility of this scenario in "Class and Class Politics in Alberta."

104. S. Pratt, "The Grip Slips," in Running on Empty pp. 107-113.

105. The committee, in which the AFL did not participate, was controversial from the day of its creation. AFL, Submission pp. 2-3; AFL and Alberta Building Trades Council, "Joint News Release: Labour Angered by Labour Law Review Committee" (Edmonton, 31 July 1986); Edmonton Journal 22 November 1986, pp. A10 and 23 November 1986, p. C6. See also: Alberta Labour, Interim Report of the Labour Legislation Review Committee (Edmonton, November 1986).

106. Edmonton Journal 29 November 1986, p. B6.

107. Edmonton Journal 29 November 1986, p. A4.

108. Edmonton Journal 13 December 1986, p. F8.

109. Harold Banister, Edmonton Chamber of Commerce, "Letter to All Edmonton Chamber of Commerce Members; Subject: Labour Legislative Review" (Edmonton, 22 December 1986).

110. Edmonton Sun 14 December 1986, p. 32.

111. Edmonton Journal 12 December 1986, p. A7.

112. Edmonton Journal 6 December 1986, p. G12. 
113. Edmonton Journal 14 December 1986, p. A2. In March 1988, Gainers "received $\$ 67$ million in provincial aid," aid which "was not offered under any existing program but (came) from the province's general revenues." The aid was not available to other packers and most of its use was left to the company's discretion. An Edmonton Journal editorial linked the financial package to the settlement of the strike, when Getty "leaned on Pocklington." When Pocklington defaulted on a payment related to this loan, in October 1989, a Globe and Mail editorial wondered about an "odd partnership" likely to "cost provincial taxpayers \$100-million." Edmonton Journal 5 March 1988, p. A6; and 8 March 1988, p. D8; Globe and Mail 12 October 1989, p. A6.

114. Bill Duckenfield, vice-president at Fletcher's: "As far as we're concerned, some of the things he's said are things that should have been left unsaid." Edmonton Journal 11 June 1986, p. E16.

115. Local 280.P v. Gainers A.L.R.B. 1986, pp. 555 and 597.

116. United Food and Commercial Workers International Union Local 280-P v. Gainers Inc., Alberta Labour Relations Board, File L.R. 302G-1 (20 November 1986), p. 658. Gainers Inc. v. United Food and Commercial Workers International Union Local 280-P and Labour Relations Board for the Province of Alberta Edmonton, No. 860328615 (Court of Queen's Bench of Alberta, 5 December 1986), pp. 13 and 16.

117. B. D. Palmer, Solidarity: The Rise and Fall of an Opposition in British Columbia (Vancouver: 1987), p. 68; Edmonton Journal, 25 July 1987, p. B2.

118. Edmonton Journal 14 December 1986, p. A5; Globe and Mail 15 December 1986, p. A1.

119. In 1987, a judge dismissed a tax reassessment appeal concluding that Pocklington "was ready to sell everything, except his wife." The sale of Wayne Gretzky confirmed this point of view. For a brief political comment, see: A. Noël and C. Couture, "La vente de Wayne Gretzky," Le Devoir 17 August 1988, p. 6. For the other information: Edmonton Journal 13 August 1987, pp. B1 and 20 August 1987, p. B1; Local 280-P v. Gainers A.L.R.B. 1986, p. 556.

120. Globe and Mail 15 December 1986, p. A1.

121. Edmonton Sun 14 December 1986, p. 4; Maclean's 29 December 1986 , p. 8.

122. Edmonton Sun 14 December 1986, p. 4.

123. E. G. Fisher and J. C. Robb, "The Labour Legislation Review Committee's Final Report 1987," Alberta Law Review 26:2 (1988), p. 316.

124. Alberta Trade Union Lawyers Association, Submission on Bill 22, Edmonton, 27 May 1988, p. 3.

125. This provision is likely to be contested as a violation of the Charter: Edmonton Journal 29 June 1988, p. B6; and 21 December, p. B4.

126. Edmonton Journal 28 November 1988, p. A1.

127. For more details, see A. Noël, "The Americanization of Alberta Labour Law," NeWest Review 13 (May 1988), p. 2. 
128. Quoted in N. Mills, "Why Local P-9 is Going it Alone," The Nation (26 April 1986), p. 578.

129. P. Rachleff, "The Hormel Strike: Turning Point for the Rank-and-File Labor Movement," Socialist Review 89 (September-October 1986), p. 93; see also: Mills, "Why Local P-9," and N. Hentoff, "Which Side is Lane Kirkland On?", The Progressive July 1986, p. 39.

130. Even if we leave the Hormel strike aside, the international has not distinguished itself by its militancy in the past and was not the most likely champion of a tough cause. In recent years the UFCW has been busier growing through mergers than it has been supporting its members. This attitude has led to the defection of $23,000 \mathrm{New}-$ foundland workers who found the union too bureaucratic and conservative. T. Dutrow, "Solidarity from Austin to Alberta," The Militant 16 January 1987, p. 4; Globe and Mail 11 April 1987, p. D2; and 24 April 1987, p. A1. On mergers as a substitute for organizing: L. Troy, "The Rise and Fall of American Trade Unions: The Labor Movement from FDR to RR," in Unions in Transition p. 91.

131. L. McClure, "Who is to Blame for Meatpackers' Misery?," The Guardian 17 June 1987, p. 5; Globe and Mail 18 March 1988, p. A10; and 27 September 1988, p. A8.

132. J. Selby, Interview, 14 July 1987. The attitude of the UFCW national representative, Vem Derraugh, was supportive but at times ambiguous. On June 12, he said: "There's no question in my mind we're going to win the strike. The only question is whether we'll have a plant to go back to." He maintained this discouraging evaluation until the settlement in December. The strikers disregarded it however. As one said: "we'd rather see the plant close down than operate non-union." Edmonton Journal 13 June 1986, p. F12; Globe and Mail 20 December 1986, p. D2; J. Selby, "Pigs and Packing Houses," p. 6.

133. "Cold War, Alberta Labour, and Social Credit," p. 151.

134. G. S. Lowe and H. Krahn, "Recent Trends in Public Support for Unions," Edmonton Area Series Report 59, Population Research Laboratory, University of Alberta, May 1988.

135. Globe and Mail 8 February 1988, p. A1.

136. Compare Alberta Report 11 July 1988, p. 8 and Globe and Mail 21 January 1989, p. D1.

137. Alberta Report 18 July 1988, p. 9.

138. Globe and Mail 23 June 1987, p. A6; Le Devoir 6 July 1987, p. 6. At the beginning of the strike, Shirley Carr referred explicitly to Gainers as an example of what Canada Post's strategy could yield. Le Devoir 16 June 1987, p. 1.

139. L.S. MacDowell, "Remember Kirkland Lake:" The Gold Miners' Strike of 1941-42 (Toronto, 1983); J. Rouillard, Histoire du syndicalisme au Québec (Montreal, 1989), pp. 278-85 and 454-57.

140. In Quebec, Raymond Malenfant, the owner of the Manoir Richelieu, has obtained the status of corporate hero sought by Pocklington. British Columbia, of course, also has its famed union bashers and 
its openly anti-union laws. G. H. Germain, "Le 'toffe' de La Malbaie," L'actualité August 1987; Le Devoir 8 May 1987, p. 1; and 16 May 1987, p. A2; Alberta Report 9 February 1987, pp. 22-6; Globe and Mail 11 May 1987, p. A1; and 27 June 1987, p. D1.

141. Davis, Prisoners p. 144; Pugh, "North Battleford's Gainers Plants."

142. Edmonton Journal 15 July 1987, p. B5. Unions do try to reach the service sector, but have little success. In 1986-87, the workers of a Mariposa clothing store in West Edmonton Mall organized a union and faced what the Labour Relations Board called "an anti-union campaign ... the likes of which have probably not been seen before in this province." The entire staff was fired four days after the first union meeting. After lengthy legal procedures, their attempt to organize failed. Edmonton Journal 22 May 1988, p. B1.

143. For union density: F. Moreau, "La force syndicale en Amérique du Nord dans les années 80," Critiques socialistes 2 (Spring 1987), pp. 68-9. On the unemployed versus union members: $M$. Simard and G. Gagnon, "The Future of the Trade Union Movement," in M. Raboy, ed., Old Passions, New Visions: Social Movements and Political Activism in Quebec (Toronto: 1986), p. 224.

144. L. McClure, "Auto Union Threatens to Cede More Ground," The Guardian 24 June 1987, p. 7.

145. See for instance: $P$. Warrian, "Trade Unions and the New International Division of Labour" and S. McBride, "Hard Times and the "Rules of the Game': A Study of the Legislative Environment of LabourCapital Conflict," in R. Argue, C. Gannag and D. W. Livingstone, eds., Working People and Hard Times: Canadian Perspectives (Toronto: 1987$)$, pp. 28 and 110.

146. J. Calvert, "Uncharted Waters: The Labour Movement's Dilemma in Developing a New Role Beyond the Bargaining System," in Argue, Gannag and Livingstone, eds., Working People and Hard Times... pp. 310-11; Panitch and Swartz, The Assault on Trade Union Freedoms p. 112. 